HJIMB Vol 2, No. 2 2020, pp: 131 - 142

https://doi.org/10.30606/hiimb

\title{
HIRARKI
}

Jurnal Ilmiah Manajemen dan Bisnis

http://iournal.upp.ac.id/index.php/Hirarki

\section{PENGARUH HARGA, RASA, LOKASI DAN IKLAN TERHADAP KEPUTUSAN PEMBELIAN AYAM PENYET PUTRI DIKOTA MEDAN}

\section{Sunday Ade Sitorus}

Departemen Manajemen, STIE ITMI, Medan , Indonesia

\section{Info Artikel \\ Sejarah Artikel: \\ Diterima 25 Maret 2020 \\ Disetujui 25 April 2020 \\ Dipublikasikan \\ 30 Juni 2020}

\section{Keywords:}

Harga, Rasa, Lokasi, Iklan

Dan Keputusan Pembelian

\begin{abstract}
Abstrak
Penelitian ini bertujuan untuk mengetahui pengaruh harga, rasa, lokasi dan iklan terhadap keputusan pembelian ayam penyet putri bagi konsumen di kota medan. Jumlah sampel tidak diketahui namun dengan mengunakan rumus penentuan sampel limeshow dan metode pengambilan sampel menggunakan accidental sampling, maka sampel ditentukan 96 orang yang berada di lima lokasi cabang Ayam penyet Putri. Hasil yang diperoleh ternyata secara keseluruhan mendapatkan nilai positif, yakni Terdapat pengaruh positif dan signifikan harga,rasa,lokasi dan iklan secara bersama-sama terhadap Keputusan Pembelian Ayam Penyet Putri. Terdapat pengaruh positif yang signifikan harga terhadap Keputusan Pembelian Ayam Penyet Putri. Terdapat pengaruh positif dan signifikan rasa terhadap Keputusan Pembelian Ayam Penyet Putri. Terdapat pengaruh positif dan signifikan lokasi terhadap Keputusan Pembelian Ayam Penyet Putri. Terdapat pengaruh positif dan signifikan iklan terhadap Keputusan Pembelian Ayam Penyet Putri. Pada akhirnya Ayam Penyet Putri sangat diminati oleh masyarakat pecinta kuliner ayam goreng..
\end{abstract}

THE INFLUENCE OF PRICE, TASTE, LOCATION AND ADVERTISING ON PURCHASE DECISION OF PRINCESS CHICKEN IN MEDAN CITY

Abstract

This study aims to determine the effect of price, taste, location and advertising on purchasing decisions for consumers in the city of Medan. The number of samples is unknown, but by using the limeshow sample determination formula and the sampling method using accidental sampling, the sample was determined to be 96 people who were in the five locations of the Ayam Penyet Putri branch. The results obtained were overall positive values, namely there is a positive and significant effect of price, taste, location and advertising together on the purchasing decision of Penyet Putri Chicken. There is a significant positive effect of price on the purchasing decision of Penyet Putri chickens. There is a positive and significant effect of taste on the purchasing decision of Penyet Putri chickens. There is a positive and significant influence of location on the purchasing decision of Penyet Putri chickens. There is a positive and significant effect of advertising on the purchasing decision of Penyet Putri chickens. In the end, Ayam Penyet Putri was in great demand by people who love fried chicken

\begin{tabular}{lr}
\hline${ }^{\square}$ Alamat korespondensi : & ISSN \\
Jalan Timah Putih Kompleks Asia Mega Mas Medan & $2684-9666($ cetak) \\
E-mail $\quad$ : sundayom.sitorus@gmail.com & $2684-8503$ (online)
\end{tabular}




\section{PENDAHULUAN}

Kebutuhan dan keinginan manusia terus berkembang dan tidak terbatas seiring dengan perkembangan zaman. Manusia tidak lagi mampu untuk memenuhi kebutuhan dan keinginannya sendiri sehingga diperlukan adanya organisasi yang dapat memenuhi kebutuhan dan keinginan manusia tersebut. Dunia bisnis terus berkembang pesat sejalan dengan perkembangan era globalisasi, hal ini ditandai dengan semakin tingginya tingkat persaingan di dunia bisnis dalam memasarkan produk maupun jasa kepada konsumen. Para pelaku bisnis saling berlomba-lomba dalam memasarkan produk yang mereka tawarkan dalam rangka memenuhi kebutuhan dan keinginan konsumen.Secara umum saat ini konsumen lebih memilih produk yang berharga murah namun memiliki kualitas yang baik, oleh sebab itu dalam kondisi persaingan yang sangat tinggi, perusahaan harus mampu memahami dan mengetahui keinginan dan kebutuhan konsumenya dan terus berinovasi untuk menciptakan positioning produknya dengan baik dan memanfaatkan keunggulankeunggulan yang ada pada produk yang ditawarkan. Menurut (Cravens, 2006) perusahaan yang gagal memahami kebutuhan, keinginan, selera proses keputusan pembelian konsumen akan mengalami kegagalan dalam pemasaran dan penjualannya. Persaingan yang ketat didalam dunia bisnis terjadi pada berbagai bidang,termasuk bisnis kuliner. Kebutuhan akan makanan dan minuman merupakankebutuhan dasar manusia yang wajib terpenuhi sehingga bisnis kuliner menjadi trend dikalangan masyarakat Indonesia.
Beberapa tahun terakhir, jumlah bisnis kuliner di Indonesia terus bertambah dengan beragam variasi produk yangditawarkan, hal ini dipengaruhi oleh terjadinya perubahan pola konsumsi dan perubahan gaya hidup konsumen Indonesia. Proses keputusan pembelian konsumen akan mengalami kegagalan dalam pemasaran dan penjualannya. Persaingan yang ketat didalam dunia bisnis terjadi pada berbagai bidang,termasuk bisnis kuliner. Kebutuhan akan makanan dan minuman merupakankebutuhan dasar manusia yang wajib terpenuhi sehingga bisnis kuliner menjadi trend dikalangan masyarakat Indonesia. . Pola konsumsi masyarakat Indonesia berubah dari makanan tradisional kemakanan moderen dan perubahan gaya hidup yang cenderung lebih memilihsesuatu yang sifatnya praktis seperti halnya mengkonsumsi makanan siap saji. Peluang inilah yang dimanfaatkan oleh para pelaku bisnis untuk ikut terjun kedalam bisnis kuliner dengan persaingan untuk memenuhi kebutuhan dan keinginan konsumen dengan produk yang mereka tawarkan sehingga membuat persaingan di dunia bisnis kuliner menjadi semakin ketat sehingga semakin banyak pula pilihan bagi konsumen memilih produk yang memuaskan kebutuhannya serta konsumen akan lebih selektif dalam membuat keputusan pembelian. Keputusan pembelian merupakan suatu keputusan sebagai pemilihan suatu tindakan dari dua atau lebih pilihan alternatif (Sumarwan, 2003). Pada pengambilan keputusan pembelian, konsumen selalu mempertimbangkan faktor-faktor yang ada seperti harga, lokasi dan kualitas produk yang didapatkan. Harga 
merupakan suatu yang diserahkan dalam pertukaran untuk mendapatkan suatu barang dan jasa (Tjiptono \& Chandra, 2018). Agar dapar sukses suatu dalam memasarkan suatu barang dann jasa , manajer harus mengintegerasiakan dengan keputusan-keputusan sebelumnya yaitu dalam bidang menciptakan suatu bauran pemasaran yang konsisten,terpatu dan mampu mencapai sasaran yang telah ditetapkan. Sedangkan (Armstrong et al., 2009) Harga adalah sejumlah uang yang dibebankan atas suatu produk atau jasa,atau jumlah dari nilai yang ditukar konsumen atas manfaatmanfaat karena memiliki atau menggunakan produk atau jasa tersebut. Menurut (Armstrong et al., 2009) ada empat indikator yang mencirikan harga yaitu: 1. Keterjangkauan harga 2. Kesesuaian harga dengan kualitas produk,3. Daya saing harga, 4. Kesesuaian harga dengan manfaat. Namun, hal penting yang harus dipahami oleh organisasi bisnis bahwa setiap konsumen memiliki perilaku yang berbeda sehingga belum tentu semua faktorfaktor tersebut akan mempengaruhinya dalam membuat suatu keputusan pembelian pada suatu bisnis. Konsumen bisa saja hanya dipengaruhi oleh satu variabel, dua variabel atau bahkan dipengaruhi oleh semua variabel tersebut, Oleh karena itu, organisasi bisnis harus memiliki pengetahuan mengenai variabel apa saja yang menjadi pertimbangan konsumen dalam membuat keputusan pembelian dan juga variabel yang paling dominan diantara ketiga variabel yang mempengaruhi keputusan pembelian sehingga organisasi bisnis dapat membuat kebijakan dan strategi yang efektif dengan kombinasi bauran pemasaran yang paling sesuai dengan kebutuhan dan keinginan konsumen. Konsumen mengharapkan produk yang dibeli memiliki kualitas yang baik dan sesuai dengan harapan agar dapat memuaskan mereka. Kepuasan konsumen dapat menjadi pertimbangan konsumen untuk melakukan pembelian ulang. Menurut (Achrol \& Kotler, 2012), kualitas produk adalah keseluruhan ciri serta dari suatu produk atau pelayanan pada kemampuan untuk memuaskan kebutuhan yang dinyatakan/tersirat. Konsumen akan merasa puas bila hasil evaluasi mereka menunjukkan bahwa produk yang mereka gunakan berkualitas.Konsumen biasanya tertarik dengan makanan yang selain rasanya enak, juga memiliki tata penyajian yang menarik.Tata penyajian yang menarik diperhatikan mulai dari wadahnya seperti bersihnya piring,mangkok ,sendok,garpu,dan piring kecil dan toping yang diberikan sebagai hiasan memper cantik penyajian.Kualitas dapat diartikan kemampuan dari produk untuk menjalankan fungsinya yang mencakup daya tahan, kehandalan atau kemajuan, kekuatan serta kemudahan dalam pengemasan dan reparasi produk dan ciri-ciri lainnya (Kotler et al., 2017). Faktor harga juga merupakan faktor penting yang menjadi pertimbangan konsumen dalam membuat keputusan pembelian pada suatu bisnis. Konsumen menginginkan harga produk yang sesuai dengan kualitas dari produk yang bersangkutan. Penetapan harga oleh pelaku bisnis harus disesuaikan dengan lingkungan dan perubahan yang terjadi.Hal tersebut akan mempengaruhi 
konsumen sebelum memutuskan pembelian karena konsumen akan mencari tau harga dan akan memilih produk yang sesuai dengan kemampuan membelinnya. Menurut (Erna, 2008) Rasa dapat digunakan pemasar menawarkana produk dengan berupaya mengasosiasikan rasa tersebut dengan perasaan konsumen. (Adinugraha \& $\mathrm{H}$ Michael, 2014) Rasa merupakan tanggapan konsumen terhadap ciri khas yang ada didalam suatu rasa produk rasa manis,asin,coklat,vanilla dan yang lainnya, yang dipengaruhi oleh factor kualitas, keaneka ragaman selera dinovasi rasa terhadap pada produk tersebut membuat keputusan pembelian. Kata " Rasa " yang menjadi motivasi konsumen dalam memilih produk adalah factor perhatian produk atau pemasar.Jadi siapa yang menjadi konsumen atau pembeli itu sangat penting diketahui oleh pihak produsen atau pemasaran. (Gladwell, 2004), Indikator Rasa Produk adalah sebagai berikut : 1 . Cita rasa yang berbeda, 2 . Adanya rasa nikmat, 3. Harapan dapat terpenuhi, 4. Menarik,5. Saling melengkapi, 6. Berkualitas. Harga merupakan sejumlah uang yang dibebankan atas suatu produk atau jasa,atau jumlah dari nilai yang ditukar konsumen atas manfaatmanfaat karena memiliki atau menggunakan produk atau jasa tersebut (Kotler \& Keller, 2013).

Lokasi merupakan salah satu faktor penting yang akan mempengaruhi konsumen dalam melakukan pembelian.Pengambilan lokasi yang baik dan strategis ialah berada dipusat kegiatan masyarakat.Lokasi yang dipilih harus lah mampu mengalami pertumbuhan ekonomi sehingga usahanya dapat bertahan. (Tjiptono \& Chandra, 2018)
Dalam memilih lokasi untuk menjalankan suatu usaha,para pengusaha/pelaku usaha perlu mempertimbangkan beberapa faktor, diantaranya : 1 . Akses yaitu kemudahan untuk menjangkau,2. Visibilitas yaitu kemudahan untuk dilihat,3. Lalu lintas,ada 2 hal yang perlu diperhatikan yaitu banyaknya orang yang lalu lalang bisa memberikan peluang yang besar tejadinya impuls buying dan kepadatan serta kemacetan bisa menjadi hambatan,4.Tempat parkir yang luas dan aman,5.Ekspansi yaitu tersedia tempat yang luas untuk perluasan dikemudian hari., 6.Lingkungan yaitu daerah sekitar yang mendukung jasa yang ditawarkan, 7.Persaingan yaitu lokasi dengan pesaing sejenis. 8 Peraturan Pemerintah. (Amaral et al., 2013) mengartikan lokasi sebagai sarana aktivitas perusahaan agar produk mudah didapatkan oleh konsumen sasarannya, sedangkan (Widjaja \& Indrawati, 2018) berpendapat bahwa yang perlu mendapat perhatian dalam hal lokasi ini meliputi banyak hal (saluran distribusi,persediaan dan transport) termasuk didalamnya tempat perusahaan beroperasi, berproduksi maupun cara penyampaian barang dari produsen kepada konsumen. Rasa aman dan nyaman serta memiliki area parkir yang luas juga menjadi pilihan konsumen karena dapat memberikan kepuasan yang lebih bagi konsumen. Ketatnya persaingan diantara pesaing menjadikan lokasi sebagai faktor penting dalam kesuksesan bisnis karena sebelum memutuskan untuk berkunjung, konsumen tentu akan mempertimbangkan juga lokasi dari tempat tersebut. Menurut (Kotler \& Keller, 2013) salah satu kunci 
menuju sukses adalah lokasi, lokasi dimulai dengan memilih komunitas. Keputusan ini sangat bergantung padapotensi pertumbuhan ekonomis dan stabilitas, persaingan, iklim politik, dan sebagainya. Menurut (Swastha Dharmmesta, 2014) lokasi adalah tempat dimana suatu usaha atau aktivitas usaha dilakukan.

(Stewart et al., 2012), Selain faktor lokasi dan harga, faktor lainnya yang memiliki peranan dalam pengambilan keputusan pembelian terhadap konsumen yaitu iklan. Iklan memiliki arti penting bagi perusahaan karena tanpa adanya iklan, perusahaan tidak akan dapat melakukan apapun dari usahanya. Pembeli akan membeli produk kalau merasa cocok, karena itu iklan disesuaikan dengan keinginan ataupun kebutuhan pembeli agar iklan berhasil, dengan kata lain, iklan lebih baik diorientasikan pada keinginan pasar atau selera konsumen. Menurut (Moriarty et al., 2012) iklan adalah jenis komunikasi pemasaran yang merupakan istilah umum yang mengacu kepada semua bentuk teknik komunikasi yang digunakan pemasar untuk menjangkau dan menyampaikan pesan kepada konsumennya. Periklanan menurut (Suhandang, 2010) adalah salah satu bentuk promosi yang paling banyak digunakan perusahaan dalam mempromosikan produknya". (Durianto et al., 2003) Iklan adalah bentuk promosi tidak langsung yang didasari pada informasi tentang keunggulan atau keuntungan suatu produk, yang disusun sedemikian rupa sehingga menimbulkan rasa menyenangkan yang akan mengubah pikiran seseorang untuk melakukan pembelian. Menurut (Kotler \& Keller, 2016) terdapat lima keputusan besar dalam periklanan, yaitu: a. Mission (Misi),b. Money (Uang atau biaya), c. Massage (Pesan), d. Media (Media),e. Measurement (Pengukuran), (Tasruddin, 2015) menyatakan bahwa indikator iklan adalah sebagai berikut: a. Dapat Menimbulkan perhatian, b. Menarik, c. Dapat menimbulkan keinginan, d. Menghasilkan suatu tindakan Memberikan manfaat berupa efisiensi waktu dan tenaga. Di Medan sendiri sudah banyak ditemui Ayam Penyet dengan berbagai konsep dan menu yang ditawarkan. Salah satunya yaitu Ayam Penyet Putri menyediakan beragam ayam goreng dan lainnya. Ayam Ayam penyet Putri saat ini memiliki cabang 5 outlet diseluruh Kota Medan. Ayam penyet Putri menawarkan berbagai Ayam penyet, Ikan Lele Penyet dan lainnya.Harga yang ditawarkan relafit murah dan terjangkau dan bersaing dengan Ayam penyet lainnya ,dimulai dengan harga Rp 5.000 samapai Rp 12.000 untuk Ayam Penyet Putri. Harga merupakan hal yang sangat diperhitungkan dalam melakukan pembelian dimana biasanya konsumen mengelukarkan budget sesuai dengan kemampuan membeli konsumen. Selanjutnya konsumen akan melihat apakah harga yang ditawarkan akan sesuai dengan kualitas produk dan apakah harga yang ditawarkan termasuk harga yang kompetitif bila dibandingkan dengan produk lain yang sejenis. Harga produk yang ditawarkan beragam berdasarkan banyaknya bahan baku produk,jenis bahan ku dan cara penyajiannya. (Kotler \& Keller, 2009) menjelaskan suatu unit bisnis umumnya tidak hanya menetapkan satu harga,tetapi mengembangkan struktur penetapan harga yang bervariasi. Lokasi merupakan hal penting yang perlu 
diperhatikan untuk membuka suatu usaha, adapun hal yang perlu diperhitungkan dalam menentukan lokasi adalah tempat yang mudah dijangkau, mudahnya transportasi umum untuk menuju lokasi,dan memiliki lahan parkir yang luas. Ayam penyet Putri berlokasi ditempattempat yang strategis serta mudah dijangkau dan banyak transpotrasi umum yang dapat digunakan untuk menuju lokasi. Namun bila tidak disertai iklan yang menarik maka Ayam penyet Putri tidak akan laku serta bergabung dengan penjualan online seperti Go-Food, Grab Food dan lainnya. Menurut (Kotler \& Armstrong, 2012) mengemukakan bahwa keputusan pembelian konsumen adalah suatu keputusan yang diambil oleh seorang calon pembeli menyangkut kepastian akan membeli atau tidak. Menurut (Kotler \& Keller, 2013) "Customer buyer behavior refers to the buying behavior of final consumers-individuals and households that buy goods and services for personal consumption". Sedangkan menurut (Peter \& Olson, 2013) keputusan pembelian merupakan "proses interaksi antara sikap afektif,sikap kognitif, sikap behavioral dengan faktor lingkungan dengan mana manusia melakukan pertukaran dalam semua aspek kehidupannya. Indikator keputusan pembelian menurut (Kotler \& Keller, 2013) terdapat lima indikator keptusan pembelian yang dilakukan oleh pembeli, yaitu1. Pilihan produk: 2 . Pilihan merek: 3. Pilihan penyalur: 4. Waktu penbelian: 5. Jumlah pembelian: 6. Metode pembayaran. Seiring dengan itu, maka kami penulis tertarik untuk meneliti terhadap pengaruh harga, rasa, lokasi dan iklan terhadap keputusan pembelian ayam penyet putri di Kota Medan.

\section{METODE}

\section{Lokasi Penelitian}

Lokasi penelitian adalah tempat melakukan penelitian guna memperoleh data penelitian. Lokasi penelitian ini adalah seluruh lima cabang Usaha Ayam Penyet Putri

\section{Populasi dan Sampel}

Populasi dalam penelitian pada tidak diketahui.sehingga digunakan rumus limeshow untuk penentuan jumlah sampel yang diambil sebagai responden dalam penelitian ini adalah seluruh jumlah populasi yang berjumlah 96 orang.

\section{Metode Pengumpulan Data}

Pengumpulan data yang akan dilakukan, yaitu dengan cara dengan melakukan penyebaran kuesioner kepada para konsumen Ayam Penyet Putri di Kota Medan. Pernyataan disusun dengan memperhatikan prinsip-prinsip penulisan angket seperti isi dan tujuan pernyataan, bahasa yang digunakan, tipe dan bentuk pernyataan, panjang pernyataan, urutan pernyataan, dan penampilan fisik angket.Teknik skala yang digunakan dalam penelitian ini adalah skala Likert.

\section{Metode Analisis data}

\section{Uji Validitas}

Pengujian validitas dilakukan dengan menggunakan SPSS versi 24.00 dengan kriteria jika nilai validitas setiap pernyataan lebih besar dari 0,30 maka butir pernyataan dianggap sudah valid. Sebaliknya, kalau korelasi antara butir dan skor total kurang dari 0,30 maka butir dalam instrumen tersebut 
dinyatakan tidak valid. Validitas adalah ukuran yang menunjukkan bahwa sejauh mana instrumen pengukur mampu mengukur apa yang akan diukur. Pengujian validitas dengan kriteria sebagai berikut :

1.Jika rhitung > rtabel maka $\mathrm{H} 1$ diterima.

2.Jika rhitung < rtabel maka $\mathrm{HO}$ ditolak.

\section{Uji Reliabilitas}

Menurut Wibowo (2014) reliabilitas adalah istilah yang dipakai untuk menunjukkan bahwa sejauh mana suatu hasil pengukuran relatif konsisten apabila pengukuran diulangi dua kali atau lebih. Pengujian reliabilitas ini dilakukan dengan tujuan untuk menguji kehandalan atau kepercayaan pengungkapan data. Pengukuran yang mampu memberi hasil yang dipercaya (reliabel). Kriteria ukur reliabilitas ini adalah jika :
1. Nilai Cronchbach's Alpha $>0,60$ maka dinyatakan reliabel.

2. Nilai Cronchbach's Alpha $<0,60$ maka dinyatakan tidak reliabel.

Peneliti menggunakan teknik analisis data sebagai berikut:

1. Metodologi Analisis Deskriptif

2. Uji Normalitas

3. Uji multikolinearitas

4. Uji heterokedastisitas

5. Analisis Regresi Linear Berganda

6. Uji-t

7. Uji F

8. Koefisien determinasi (R2).

HASIL DAN PEMBAHASAN

\section{Uji Normalitas Data}

Uji normalitas digunkan untuk mengetahui apakah variabel independen dan variabel dependen atau keduanya berdistribusi normal atau tidak.

Tabel 1. Hasil Uji One-Sample Kolmogorov-Smirnov Test

\section{One-Sample Kolmogorov-Smirnov Test}

Unstandardized Residual

\begin{tabular}{|c|c|c|}
\hline & 96 \\
\hline \multicolumn{3}{|l|}{ Normal } \\
\hline \multicolumn{3}{|l|}{ Parameters ${ }^{\mathrm{a}, \mathrm{b}}$} \\
\hline Most Extreme & Absolute & , 169 \\
\hline \multirow{2}{*}{ Differences } & Positive & ,242 \\
\hline & Negative &,- 169 \\
\hline \multicolumn{2}{|c|}{ Kolmogorov-Smirnov Z } & ,169 \\
\hline \multicolumn{2}{|c|}{$\begin{array}{l}\text { Asymp. Sig. (2-tailed) } \\
\text { a. Test distribution is Normal. } \\
\text { b. Calculated from data. }\end{array}$} &, $100^{\mathrm{c}, \mathrm{d}}$ \\
\hline
\end{tabular}

Sumber: data yang diolah (2019)

Dari hasil pengolahan data pada tabel signifikan pada 0,100 . Nilai signifikansi diatas, diperoleh besarnya nilai diartikan data residual tersebut Kolmogorov-Smirnov adalah 0,169 dan berdistribusi normal.maka dapat 
disimpulkan bahwa analisis lebih lanjut dapat dilakukan dengan menggunakan model regresi berganda.

\section{Uji Multikolinearitas}

Uji multikolinearitas bertujuan untuk menguji apakah terdapat kolerasi antara variabel independen dalam model regresi.Jika pada model regresi terjadi multikolinearitas, maka koefisien regresi tidak dapat ditaksir dan nilai staandard error menjadi tidak terhingga

\section{Coefficients $^{\mathrm{a}}$}

Tabel 2. Hasil Uji Multikolinearitas

\begin{tabular}{|ll|r|r|}
\hline \multirow{2}{*}{ Model } & \multicolumn{2}{|c|}{ Collinearity Statistics } \\
\cline { 2 - 3 } & (Constant) & \multicolumn{1}{|c|}{ Tolerance } \\
HARGA & & \\
& &, 871 & \\
& RASA &, 597 & 1,130 \\
& LOKASI &, 569 & 2,451 \\
& IKLAN &, 502 & 2,617 \\
& & 2,191 \\
\hline
\end{tabular}

Sumber: data yang diolah (2019)

Dari data pada taabel diatas dapat diketahui bahwa bilai Variance InflationFactor (VIF) untuk variabel harga sebesar 1,130 , rasa sebesar 2,451, lokasi sebesar 2,617 dan iklan sebesar 2,191. Demikian juga dengan nilai Tolerance pada harga sebesar 0,871 , rasa sebesar 0,597, lokasi sebesar 0,569 dan iklan sebesar 0,502 dari masing-masing variabel ini tolerance lebih besar dari 0,1 sehingga dapat disimpulkan bahwa tidak terjadi gejala multikolinearitas antara variabel independen yang diindikasikan dari nilai tolerance setiap variabel independen lebih besar dari 0,1 dan nilai VIF lebih kecil dari 10, maka dapat disimpulkan bahwa analisis lebih lanjut dapat dilakukan dengan menggunakan model regresi berganda.

\section{Uji Heterokedastisitas}

Uji heterokedastistas bertujuan menguji apakah dalam model regresi terjadi ketidaksamaan variance dari residual pengamatan ke pengamatan lain. Model regresi yang baik adalah tidak terjadi
heterokedastistas.Alat uji yang digunakan untuk mengukur gejala heteroskedastisitas adalah Uji Glejser. Menurut (Ghozali, 2006) model regresi yang baik ialah yang tidak mengandung gejala heteroskedatisitas dinyatakan tidak akan, jika nilai signifkansi lebih besar dari alpha 0,05 
Tabel 3. Uji Heterokedastisitas

\section{Coefficients ${ }^{a}$}

Model

(Constant)

HARGA

RASA

LOKASI

IKLAN
Sig.

,125

,257

,324

,294

,374

a. Dependent Variable: abs_res_1

Sumber: data yang diolah (2019)

Hasil uji heteroskedesitas menunjukan bahwa nilai Sig. dari variabel harga $\left(\mathrm{X}_{1}\right)$, rasa $\left(\mathrm{X}_{2}\right)$, lokasi $\left(\mathrm{X}_{3}\right)$ dan iklan $\left(\mathrm{X}_{4}\right)$ sebesar 0,257,0,324,0,294 dan 0,374 yang artinya nilai variabel lebih besar dari 0,05 yang berarti tidak terdapat pengaruh antara variabel bebas terhadap absolute residual. Dengan demikian, model yang dibuat tidak mengandung gejala heteroskedastisitas. maka dapat disimpulkan bahwa analisis

lebih lanjut dapat dilakukan dengan menggunakan model regresi berganda.

\section{Uji Regresi Linier Berganda}

Dalam menganalisis data digunakan analisis regresi linear berganda.Dimana analisis berganda untuk mengetahui pengaruh dari masing-masing variabel bebas terhadap variabel terikat.Berikut hasil pengolahan data dengan menggunakan SPSS versi 24.0

Tabel 4. Uji Regresi Linear Berganda

\begin{tabular}{|c|c|c|c|}
\hline \multicolumn{3}{|c|}{ Coefficients $^{\mathbf{a}}$} & \multirow{4}{*}{$\begin{array}{c}\text { Standardized } \\
\text { Coefficients } \\
\text { Beta }\end{array}$} \\
\hline & Unstanda & Coefficients & \\
\hline Model & B & Std. Error & \\
\hline (Constant) & 2,384 & 5,287 & \\
\hline HARGA & 673 & ,263 & 025 \\
\hline RASA & ,532 & , 213 & ,321 \\
\hline LOKASI & 328 & 218 & 187 \\
\hline IKLAN & 679 & 190 & ,497 \\
\hline
\end{tabular}

a. Dependent Variable: total.y

Sumber: data yang diolah (2019)

Hasil tersebut dimasukkan kedalam $Y=2,384+0,273 X 1+0,532 X 2+0,328$ persamaan regresi linier berganda sehingga diketahui persamaan berikut :

\section{$\mathrm{X} 3+0,679 X 4$}

Keterangan :

Koefisien regresi menunjukan bahwa setiap variabel independen yang diuji 
berpengaruh positif terhadap variabel dependen.

a) Konstanta 2,384 berarti jika harga, rasa, lokasi, iklan maka keputusan pembelian konsumen adalah 2,384 yang berarti bahwa tingkat kep

b) Koefisien regresi harga 0,673 yang berarti hanya $67,3 \%$ yang menyatakan bahwa harga sangat menentukan keputusan pembelian

c) Koefisien regresi rasa 0,532 yang Berarti lokasi memiliki nilai $53,2 \%$ yang menyatakan bahwa lokasi menentukan keputusan pembelian

d) Koefisien regresi lokasi 0,328 yang menunjukan bahwa lokasi memiliki nilai 32,8 \% yang berarti bahwa lokasi tidak terlalu dibutuhkan untuk keputusan pembelian.

e) Koefisien regresi iklan 0,679 yang menunjukan bahwa iklan memiliki nilai $67,9 \%$ yang berarti bahwa iklan dalam mempromosikan usaha sangat berperan untuk keputusan pembelian,

\section{Uji Hipotesis}

Uji Signifikan Parsial (Uji Statistik

t)

Uji t dipergunakan dalam penelitian ini untuk mengetahui kemampuan dari masing-masing variabel independen dalam mempengaruhi variabel dependen. Alasan lain uji t dilakukan yaitu untuk menguji apakah varoabel bebas (X) secara individual terdapat hubungan yang signifikan atau tidak terhadap variabel terikat

Tabel 5. Uji Partial

\section{Hasil Uji Parsial (Uji-t)}

Coefficients $^{a}$

$\begin{array}{cc}\text { Unstandardized } & \text { Standardize } \\ \text { Coefficients } & \mathrm{d} \\ \text { Coefficients }\end{array}$

Std.

\begin{tabular}{llrcrrr} 
Model & & B & Error & Beta & \multicolumn{1}{c}{ T } & Sig. \\
1 & (Constant) & 2,384 & 5,287 & & 1,432 &, 001 \\
& HARGA &, 673 &, 263 &, 025 &, 612 &, 002 \\
& RASA &, 532 &, 213 &, 321 & 0,767 &, 000 \\
& LOKASI &, 328 &, 218 &, 187 & 0,607 &, 001 \\
& IKLAN &, 679 &, 190 &, 497 & 0,819 &, 000
\end{tabular}

a. Dependent Variable: total.y

Sumber : Data yang diolah (2019)

Hasil penelitian statistik $\mathrm{t}$ pada tabel diatas dapat dijelaskan sebagai berikut :

1. Berdasarkan hasil pengujian parsial pengaruh antara
Pendidikan Kewirausahaan terhadap Keputusan Pembelian Ayam Penyet Putri diperoleh thitung adalah 0.612 dan tabel dengan $\alpha=$ $5 \%$ diketahui sebesar 1.980, 
dengan tingkat signifikan $0,002<$ 0,05 . Dari hasil tersebut dapat disimpulkan bahwa $\mathrm{H}_{\mathrm{o}}$ ditolak hal ini menunjukkan bahwa terdapat pengaruh dan signifikan antara harga terhadap Keputusan Pembelian Ayam Penyet Putri

2. Berdasarkan hasil pengujian parsial pengaruh antara Rasa terhadap Keputusan Pembelian Ayam Penyet Putri diperoleh thitung adalah 0.767 dan tabel dengan $\alpha=$ $5 \%$ diketahui sebesar 0,000 , dengan tingkat signifikan $0,000<$ 0,05 . Dari hasil tersebut dapat disimpulkan bahwa $\mathrm{H}_{\mathrm{o}}$ ditolak, hal ini menunjukkan bahwa ada pengaruh yang signifikan antara Rasa terhadap Keputusan Pembelian Ayam Penyet Putri

3. Berdasarkan hasil pengujian parsial pengaruh antara Lokasi terhadap Keputusan Pembelian Ayam Penyet Putri diperoleh thitung adalah 0.607 dan tabel dengan $\alpha=5 \%$ diketahui sebesar ,001, dengan tingkat signifikan 0,001<0,05. Dari hasil tersebut dapat disimpulkan bahwa $\mathrm{H}_{\mathrm{o}}$ ditolak, hal ini menunjukkan bahwa terdapat pengaruh yang signifikan antara lokasi terhadap Keputusan Pembelian Ayam Penyet Putri

4. Berdasarkan hasil pengujian parsial pengaruh antara iklan terhadap Keputusan Pembelian Ayam Penyet Putri diperoleh thitung adalah 0,819 dan tabel dengan $\alpha=5 \%$ diketahui sebesar 1.980, dengan tingkat signifikan $0,000<0,05$. Dari hasil tersebut dapat disimpulkan bahwa $\mathrm{H}_{\mathrm{o}}$ ditolak, hal ini menunjukkan bahwa ada pengaruh yang signifikan iklan terhadap Keputusan Pembelian Ayam Penyet Putri

\section{Uji Simultan (Uji f)}

Berdasarkan hasil pengolahan data dengan menggunakan program SPSS Versi 24.0, maka diperoleh hasil sebagai berikut:

Tabel 6.Uji Simultan (Uji F)

Hasil Uji Simultan (Uji-F) ANOVA $^{a}$

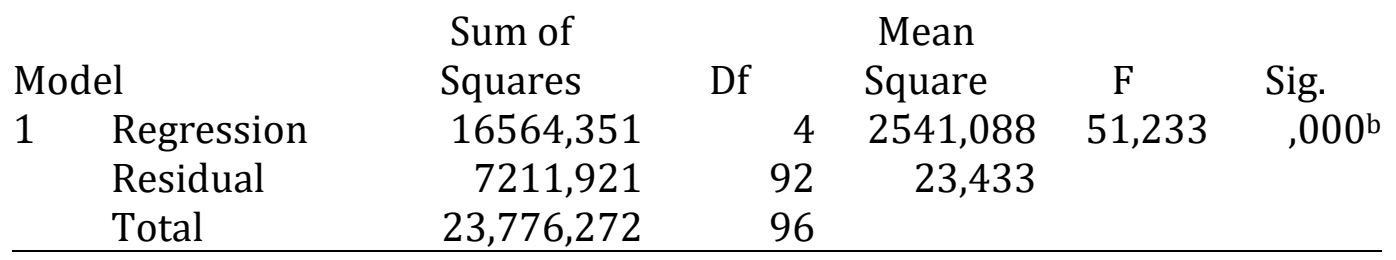

a. Dependent Variable: total.y

Sumber : Data yang diolah (2019)

Tabel 7. Uji Korelasi

Model Summary

\begin{tabular}{lrrrr}
\hline & \multicolumn{2}{c}{ Adjusted R } & \multicolumn{2}{c}{ Std. Error of the } \\
Model & $\mathrm{R}$ & R Square & Square & \multicolumn{2}{c}{ Estimate } \\
1 &, $555^{\mathrm{a}}$ &, 643 &, 612 & 7,750 \\
\hline
\end{tabular}

Sumber : Data Yang Diolah (2019) 
Dapat dilihat dari hasil diatas nilai sig $\mathrm{F}$ $<0,05(0,000<0,05)$ dan $\mathrm{F}$ hitung $>\mathrm{F}$ tabel $(51,233>2,447)$, maka $\mathrm{H}_{0}$ ditolak. Jadi terdapat pengaruh positif dan signifikan harga,rasa,lokasi dan iklan secara bersama-sama terhadap Keputusan Pembelian Ayam Penyet Putri.

\section{Koefisien Determinasi}

Koefisien determinasi ini berfungsi untuk mengetahui persentase besarnya pengaruh variabel independen dan variabel dependen yaitu dengan mengkuadratkan koefisien yang ditemukan. Dalam penggunaanya, koefisien determinasi ini dinyatakan dalam persentase harga,rasa,lokasi dan iklan secara bersama-sama terhadap Keputusan Pembelian Ayam Penyet Putri maka dapat diketahui uji determinasi

\section{SIMPULAN DAN SARAN}

Berdasarkan data yang diperoleh dari hasil analisis yang dilakukan makadapat ditarik kesimpulan sebagai berikut: Terdapat pengaruh positif dan signifikan harga,rasa,lokasi dan iklan secara bersama-sama terhadap Keputusan Pembelian Ayam Penyet Putri. Terdapat pengaruh positif yang signifikan harga terhadap Keputusan Pembelian Ayam Penyet Putri. Terdapat pengaruh positif dan signifikan rasa terhadap Keputusan Pembelian Ayam Penyet Putri. Terdapat pengaruh positif dan signifikan lokasi terhadap Keputusan Pembelian Ayam Penyet Putri. Terdapat pengaruh positif dan signifikan iklan terhadap Keputusan Pembelian Ayam Penyet Putri.

\section{DAFTAR PUSTAKA}

Achrol, Ravi S., And Philip Kotler. 2012. "Frontiers of The Marketing Paradigm In The Third Millennium." Journal of The Academy Of Marketing Science 40 (1): 35-52. Https://Doi.Org/10.1007/S11747 -011-0255-4.

Adinugraha, Andreas T, And Stefanus H Michael. 2014. "Analisa Pengaruh Kualitas Makanan Dan Persepsi Harga Terhadap Kepuasan Konsumen D'cost Surabaya." Hospitality Dan Manajemen Jasa. Amaral, G., J. Bushee, U. G. Cordani, Koji Kawashita, J. H. Reynolds, Fernando Flávio Marques De E Almeida, F. F.M. De Almeida, Et Al. 2013. Marketing Kotler. Journal Of Petrology. Https://Doi.Org/10.1017/Cbo978 1107415324.004.

Armstrong, Gary, Philip Kotler, Michael Harker, And Ross Brennan. 2009. Marketing: An Introduction. Pearson.

Https://Doi.Org/10.1016/01664972(92)90011-6.

Cravens, David. 2006. "Strategic Marketing's Global Challenges And Opportunities." Handbook Of Business Strategy. Https://Doi.Org/10.1108/107757 30610618639.

Durianto, D., Sugiarto, A. W. Widjaja, And H. Supratikno. 2003. "Invasi Pasar Dengan Iklan Yang Efektif." Jakarta: Pt. Gramedia Pustaka Utama.

Erna, Ferrinadewi. 2008. Merek Dan Psikologis Konsumen Impikasi Pada Strategi Pemasaran. Jurnal Manajemen Dan Kewirausahaan.

Ghozali, Imam. 2013. "Aplikasi Analisis Multivariate Dengan Program Ibm 
Dan Spss." In Aplikasi Analisis Multivariate Dengan Program Ibm Spss 19, 113. Https://Doi.Org/10.2307/157994 1.

Gladwell, Malcolm. 2004. "Taste Technologies: Ketchup Conundrum." The New Yorker.

Kotler, Philip, And Gary Armstrong. 2012. "Marketing: Creating And Capturing Customer Value." In Principles Of Marketing.

Kotler, Philip, And Kevin Lane Keller. 2009. Marketing Management. Organization. Vol. 22. Https://Doi.Org/10.1080/089117 60903022556.

_-_. 2013. Marketing Management 14e. Pearson Education Limited. Pearson. Vol. 22. Https://Doi.Org/10.1080/089117 60903022556.

———. 2016. Markkotler, P., \& Keller, K. L. (2016). Marketing Management. Global Edition (Vol. 15e). Global Edition.

Moriarty, Sandra, Nancy Mitchell, And William Wells. 2012. Advertising \& Imc: Principles And Practice (9th Edition). Pearson Education, Inc.

Peter, Paul J, And Jerry C Olson. 2013. Perilaku Konsumen Dan Strategi Pemasaran. Salemba Empat.

Purwantoro, P., \& Afrizal, A. (2019, August). Evaluation of items on instruments of consumer attitudes, word of mouth, and decisions of private universities.
In Journal of Physics: Conference Series (Vol. 1255, No. 1, p. 012092). IOP Publishing.

Stewart, H. Rewoldt, Prof. James D Scott, And Prof. Martin R Warshaw. 2012. "Komunikasi Pemasaran." Humaniora 3 (1): 215-22.

Suhandang, Kustadi. 2010. "Periklanan; Manajemen, Kiat Dan Strategi." In Bandung: Nuansa.

Sumarwan, U. 2003. Perilaku Konsumen: Teori Dan Penerapannya Dalam Pemasaran. Ghalia Indonesia, Bogor. Https://Doi.Org/10.1007/Bf0101 3984.

Swastha Dharmmesta, Basu. 2014. "Peran Pemasaran Dalam Perusahaan Dan Masyarakat." In Marketing Management, 1-38. Http://Repository.Ut.Ac.Id/4785/ 1/Ekma4216-M1.Pdf.

Tasruddin, Ramsiah. 2015. "Strategi Promosi Periklanan Yang Efektif." Strategi Promosi Periklanan Yang Efektif.

Tjiptono, Fandy, And Gregory. Chandra. 2018. "Manajemen Kualitas Jasa." Yogyakarta.

Andi. Https://Doi.Org/10.12691/Jbms4-4-1.

Widjaja, Andrew Effendy, And Lilik Indrawati. 2018. "Pengaruh Lokasi, Harga, Promosi, Dan Kualitas Pelayananterhadap Keputusan Menggunakan Ojek Online." Jurnal Bisnis Terapan. Https://Doi.Org/10.24123/Jbt.V2i 02.1617 . 